\title{
Further Empirical Examination on Determinants of Bank Credit Growth in Nigeria: A Supply Side Approach
}

\author{
OLOFINLADE Samuel Oluwapelumi \\ Department of Finance, Faculty of Management Sciences, \\ Ekiti State University, Ado-Ekiti, Nigeria
}

\begin{abstract}
This study examined and carried out further examination on the determinants of aggregate bank credit growth in Nigeria from the period of 1984 to 2020 . It specifically investigates the determinants of bank credit growth to private and public sectors of the Nigerian economic growth performance. The study employed econometric approach to further carried out the examination on the determinants of aggregate bank credit growth in Nigeria by applying the estimation techniques of Augmented Dickey Fuller (ADF)/unit root test, correlation analysis and ordinary fitted regression analysis. The study addressed broad money supply, monetary policy rate, inflation rate, exchange rate and real gross domestic product as explanatory variables while aggregate bank credit to private and public sectors was regressed as the explained variables. The data used for the analysis were gathered from secondary sources of Nigeria Central Bank Statistical Bulletin and National Bureau of Statistics. The findings revealed that monetary policy rate, money supply and real gross domestic product have significant and positive effects on aggregate credit to private and public sectors (credit growth) aside exchange and inflation that have a negative and insignificant effect. The effect of these is that macroeconomic variables used are the true parameter of measuring aggregate bank credit growth in Nigeria. The short run result and regression results validates and support the influence of aggregate bank credit as a major determinant of credit supply via financial and non financial intermediaries. While the financial reforms and bank reforms also strengthen the banking sector towards meeting their obligations towards investment proliferation and economic growth performance.
\end{abstract}

JEL Classification Numbers: E44, E51, G21

Keywords: Bank credit, Aggregate credit to private and public sector, SMEs, Nigeria

DOI: $10.7176 /$ RJFA/12-11-02

Publication date:June $30^{\text {th }} 2021$

\section{Introductions}

Determinants of bank credit in Nigeria have recently been a topic of growing concern worthy of empirical investigation among reputable scholars; particularly in view fluctuations of the boom-bust cycles experienced in Nigeria financial system before and after the recent global financial crisis. However, finance is the bedrock of every business, as business grows; it needs more funds to expand its numerous operational and non-operational activities. To finance such activities any organization has two main sources of funding; internal and external. The loan from financial institutions like equities, deposit money banks, mutual funds and pension fund are the key source among the major external source of funding for business while retain earning and ploughing back profit are major internal source of fund.

In order to actualise their financial needs, businesses mostly don't base their capital structure entirely within their internal funds but on the combination of equity and debt (capital gearing). However, small and medium scale enterprises (SMEs) firms do have inadequate sources of raising funds hence the establishment of Second tier market to facilitate borrowing by SMEs for their various uses of fund. So to find the determinants of bank credit is a crucial issue to discuss because of the growing trend of using bank loan in the world economies to finance projects. The existing literature reveals that the availability of bank credit plays a meaninful function to boost up the economic performance and growth especially in developing economies like Nigeria.

In the light of the above one tend to ask the fundamental question of what determines credit growth in Nigeria? What are the main thing that permeates pre- crisis credit upsurge in Nigeria and what has led to the collapse of some financial institutions? Does an efficient financial reform act as a determinants to bank credit? Does financial liberation facilitate efficient bank credit? The study also covers bank credit behaviour during the pre- financial reform and post- financial reform periods. The broad objective of the study is to carry out some further empirical analysis on the determinants of bank credit from the supply side in Nigeria. The hypothesis formulated was tested in null form so as to be in line with the above stated objectives. For the purpose of this research, the hypothesis formulated states that aggregate banks' credit does not have significant effects on credit growth in Nigeria.

This paper tries to shed light on these questions by applying econometric approach in investigating data on macroeconomic variables of monetary policy rate (MPR), inflation (INF), exchange rate (EXG), real gross domestic product (RGDP) and aggregate bank credit to private and public sectors (BCr-credit growth) over the last decade, covering both pre-crisis and post-crisis periods i.e from 1984 to 2020. Answering these questions 
will provide insights into the empirical relationship between financial sector reforms and their implications for banks' credit supply to other sectors. The study is divided into five sections: introduction, literature review, research method, result and discussion of findings and the conclusion and recommendations.

\subsection{Review of related concepts and empirical studies}

Baoko. G., Acheampong, A.I \& Ibrahim.M., (2017) the study investigate the determinants of bank credit in Ghana Using the Autoregressive Distributed Lag (ARDL) framework, the study examines the relevant factors permeating the allocation of bank credit to the private sector in the Ghanaian economy for the period 1970 to 2011. The findings reveal that broad money supply, bank assets, real lending rate, and bank deposits are meaningful determinants of bank credit in both the short and long-run. Inflation also exerts meaningful positive effect only in the short-run. The study infers the lack of successive governments' commitment to pursue policies that boost the supply of credit to the private sector. Their findings further reveal that increases in deposits mobilization by banks does not necessarily translate into supply of credit to the private sector. A laudable deduction from the outcome is that reduced government's domestic borrowing, lower cost of borrowing, and lower central bank reserve requirements for commercial banks in Ghana are needed to enhance higher lending and credit demand.

Kai .G., \& Vahram. S. (2011) examines changes in bank credit across a wide range of developing market economies. Time-series and cross-section information was regressed and used on quarterly data series which were obtained from the secondary sources. The data ranges from the time of first quarter of 2001 to the second quarter of 2010 and covers 38 countries. The findings revealed all the estimated parameters are significant with expected signs. Both domestic deposits and liabilities to non-residents contribute positively to private credit growth. This seems to suggest that banks treat domestic funding and foreign funding symmetrically-for every penny of additional funding, be it from domestic sources or foreign sources, half of that will be lent out to the private sector on average. Private credit also increases with inflation, but less than one to one, which implies that inflation in fact reduces real private credit growth. Higher GDP growth leads to more demand for credit and hence higher credit growth, while a higher deposit rate signals contractionary monetary conditions and thereby less credit growth. Global allows us to draw wider lessons compared to many existing researches, which focus on a specific set of developing market economies or on shorter time periods. Our results show that domestic and foreign funding contributes positively and symmetrically to credit growth. The results also indicate that stronger economic growth leads to higher credit growth, and high inflation, while increasing nominal credit, is inimical to real credit growth. We also find that ease monetary conditions, either domestic or global, result in more credit, and that the health of the banking sector also matters.

Assefa .M. (2014) examined the determining factors of bank credit to private sector in Ethiopian enviromentand its effects both in the short and long-run . the study made use of supply-side method the study empirically examine using a time series annual data over the period1978/79-2010/11. The study applied ARDL econometric method. In the study bank credit to the private sector was used as dependent variable while domestic deposit, foreign liabilities, lending interest rate, reserve requirement, M2 as percentage of NGDP, RGDP and inflation are the explanatory variables. The finding outcome shows that domestic deposits, foreign liabilities, real lending interest rate, M2 as percentage of NGDP, GDP and inflation have meaningful effects on banks credit to the private sector in the long-run. Conversely reserve requirement does not affect commercial banks credit to private sector both in long and short-run. Moreover, in the short-run domestic deposit and economic growth do not permeates commercial banks credit to private sector.

Kashif .I \& Mohammed N. (2013). Determinants of bank credit in Pakistan: A supply side approach. This study is on the factors which explain the bank credit to the businesses in changing financial environments and emerging global challenges. The study uses the ARDL econometric approach on annual data from the period 1971 to 2010 for Pakistan. The findings results reveals that the foreign liabilities, domestic deposits, economic growth, exchange rate, and the monetary conditions are meaningfully related with bank credit to the private sector in Pakistan, particularly in the long run. Whereas the inflation and money market rate does not affect the private credit. Moreover, in the short run the domestic deposit does not permeate private credit. The findings also deduced that the financial health and liquidity of the banks play a meaningful and vital function in the determination of loan. Results also shows that the long run nexus is stable and any disequilibrium formed in the short run will be temporary and get corrected over a period of time with a high speed of $53.5 \%$ per year. This study does not statistically distinguish the behaviour of bank credit during non-financial (1971-1989) and financial reform periods (after 1990) in Pakistan.

Olokoyo. F. O (2013). Determinants of commercial banks' lending behaviour in Nigeria. . The study aimed to test and confirm the effectiveness of the common determinants of commercial banks' lending behaviour and how it affects the lending behaviour of commercial banks in Nigeria. The model used is estimated using Nigerian commercial banks' loan advance (LOA) and other determinants or variables such as their volume of deposits (Vd), their investment portfolio (Ip), interest (lending) rate (Ir), stipulated cash reserve requirements 
ratio $(\mathrm{Rr})$ and their liquidity ratio $(\mathrm{Lr})$ for the period; $1980-2005$. The model hypothesizes that there is functional nexus between the dependent variable and the specified independent variables. From the regression analysis, the model was found to be meaningful and its estimators turned out as expected and it was discovered that commercial banks deposits have the greatest effects on their lending behaviour.

Langat, R .C (2013) investigates the determinants of lending to farmers by commercial banks in Kenya, The study was done through a survey using self administered structured questionnaires handed over to commercial banks in Kenya vis-a-vis their policies on Credit Standards with Regard to Farmers; their Assessment of Return on Credit to Farmers; and their assessment of Risk on Credit to Farmers. The results reveals that banks give out loans to finance farming activities and that farmers have tangible sources of income that enable them to pay back their loans in time. The results established that Credit Standards Credit Standards Regard to Farmers negatively impacted lending to farmers. The research has also found that Return on Credit to Farmers negatively affected lending policy to farmers. Further, Risk on Credit to Farmers negatively affected lending to farmers. This shows that Credit Standards with Regard to Farmers; Return on Credit to Farmers; and Risk on Credit to Farmers diminishes the amounts provided to the farmers in Kenya.

\subsection{Methodological framework}

The researcher adopts econometric technique to examine the determinants of bank credit growth in Nigeria: a supply side approach using different techniques such as the Augmented Dickey-Fuller (ADF)/ unit root test, correlation matrix analysis and ordinary lease fitted regression.

\subsection{Specification of the model}

A model was form to suit this study so as to achieve the stated objective with adequate variables in order to improve the fit, thereby estimating the most likely relationship among the variables. Furthermore, the monetary policy instruments of money supply (MS), monetary policy rate (MPR), exchange rate (EXG) and inflation (INF) was used as the independent variables while aggregate credit to private and public sectors $\left(\mathrm{BCr}_{\text {credit growth }}\right)$ as dependent variable. This was stated below as:

$\mathrm{BCr}_{\text {credit growth }}=f\left(\mathrm{MS}_{2}, \mathrm{MPR}, \mathrm{EXR}, \mathrm{INF}, \mathrm{RGDP}, \mathrm{Ut}\right)$ 1

Expressing equation (1) more explicitly, we have:

$\mathrm{BCr}_{\text {credit growth }}=\beta_{0}+\beta_{1} \mathrm{MS}_{2},+\beta_{2} \mathrm{MPR}+\beta_{3} \mathrm{EXR}+\beta_{4} \mathrm{INF}+\beta_{5} \mathrm{RGDP}+\mathrm{U}_{\mathrm{t}} \ldots \ldots \ldots . .2$

Where: $\beta_{0}=$ Constant intercept; $\beta_{1}-\beta_{5}=$ Parameters or coefficients to be estimated; $f=$ Functional notation and $\mathrm{U}_{\mathrm{t}}=$ Stochastic error term.

\subsection{Estimation technique variables, samples and data source}

This study adopts Augmented Dickey- Fuller (ADF) /unit root test, correlation matrix analysis, and econometric modelling using OLFS in evaluating and analyzing the results of the determinants of bank credit from the supply side. The study made use of secondary data of annual series obtained from the Central Bank of Nigeria statistical bulletin and National Bureau of Statistics. All data on real gross domestic product (RGDP), aggregate credit to private and public sector $\left(\mathrm{BCr}_{\text {credit growth }}\right)$, monetary policy rate (MPR), exchange rate(EXG), money supply (MS) and inflation rate (INF). The time series annual data covered the period 1984-2020.

A priori expectation is determined by the principles of economic theory and it refers to the expected relationship between the explained variable and the explanatory variable(s). $\beta 4 \leq 0 \beta_{5} \geq 0$

$\beta_{0} \neq 0 ; \beta_{1} \geq 0 ; \beta_{2} \geq 0 ; \beta 3 \leq 0 ;$

\subsection{Presentation of Results and Discussion}

The results of the findings from the study are presented sequentially and discussed as follows:

\subsection{Stationarity Test or Unit Root Test}

The study performed the Augmented Dickey-Fuller (ADF) unit root test to ascertain the stationarity of the time series variables in order to avoid spurious result from modelling non stationary variables. The result of the test is presented in Table 1.

Table 1 Summary of Unit Root Test

\begin{tabular}{|c|c|c|c|c|}
\hline Variables & ADF test statistic & Critical value 5\% & Integration & Remark \\
\hline RGDP & -3.161318 & -2.957110 & $1(1)$ & Stationary \\
\hline MS $_{2}$ & -3.492146 & -2.957110 & $1(1)$ & Stationary \\
\hline MPR & -6.964028 & -2.957110 & $1(1)$ & Stationary \\
\hline EXR & -6.042668 & -2.957110 & I $(1)$ & Stationary \\
\hline INF & -3.994322 & -2.957110 & I $(1)$ & Stationary \\
\hline BCr & -4.979052 & -2.957110 & I $(1)$ & Stationary \\
\hline
\end{tabular}

Source: E view 9 Statistical, (2020) 
The unit root test in Table 1 showed that all the macroeconomic variables used were stationary at first difference. The real gross domestic product, money supply, prime lending rate, monetary policy rate, exchange rate and inflation rate failed stationary test at level but all became stationary at first difference. The reason behind this is that the Augmented Dickey Fuller (ADF) test statistics of each of the macroeconomic variables used was greater than 5 percent critical value of each of the variables in absolute terms. This result implies that there is a short run equilibrium relationship among the economic variables under investigation. The dynamic nature of the variables as revealed by the unit root test led to the adoption of correlation test and ordinary lease fitted regression test. The ordinary lease fitted regression is an appropriate model to determine the existing relationship among the variables and aggregate banks' credit in Nigeria.

\subsection{Correlation Analysis}

Correlation test was carried out to indicate the degree of association among the studied variables in the model.

Table 2 Correlation Matrix

\begin{tabular}{|c|c|c|c|c|c|c|}
\hline & RGDP & $\mathrm{MS}_{2}$ & MPR & INF & EXR & BCredit \\
\hline $\mathrm{RGDP}$ & 1.000000 & 0.971780 & 0.344275 & 0.160670 & 0.830167 & 0.978134 \\
\hline $\mathrm{MS}_{2}$ & 0.971780 & 1.000000 & 0.299429 & 0.124153 & 0.927640 & 0.997980 \\
\hline $\mathrm{MPR}$ & 0.344275 & 0.299429 & 1.000000 & 0.398564 & 0.093378 & 0.302507 \\
\hline $\mathrm{INF}$ & 0.160670 & 0.124153 & 0.398564 & 1.000000 & 0.001474 & 0.160697 \\
\hline $\mathrm{EXR}$ & 0.830167 & 0.927640 & 0.093378 & 0.001474 & 1.000000 & 0.913617 \\
\hline $\mathrm{BCr}_{\text {credit }}$ & 0.978134 & 0.997980 & 0.302507 & 0.160697 & 0.913617 & 1.000000 \\
\hline
\end{tabular}

Source: E view 9 Statistical Package, (2020)

Tables 2 revealed the correlation result among the variables of real gross domestic product, money supply, inflation, exchange rate and aggregate banks' lending rate respectively. Table 2 explicitly revealed that there is a positive correlation between real gross domestic product (RGDP) and money supply $\left(\mathrm{MS}_{2}\right)$, real gross domestic product (RGDP) and monetary policy rate (MPR), real gross domestic product (RGDP) and inflation (INF), real gross domestic product (RGDP) and exchange rate (EXR) real gross domestic product (RGDP) and aggregate banks' lending $\left(\mathrm{BCr}_{\text {credit growth }}\right)$ with the correlation coefficient of $0.97,0.34,0.16,0.83$ and 0.97 respectively. Thus, it can be established based on the result of the correlation matrix that the variables contributed significantly and serve as an engine device to drive the banks' lending and economic performance in Nigeria.

\subsection{Fitted Regression Model}

It should be recalled that there are research questions, objective and hypothesis in this study. This was tested accordingly. In order to test Hypothesis which stated that aggregate banks' credit $\left(\mathrm{BCr}_{\text {credit growth }}\right)$ does not have significant effects on credit growth in Nigeria fitted regression estimate was employed on the variables of interest namely; $\mathrm{BCr}_{\text {credit growth }}, \mathrm{RGDP}, \mathrm{MS}_{2}, \mathrm{MPR}, \mathrm{EXR}, \mathrm{INF}$

Table 3 Regression Result of Determinants of Bank Credit Growth

\begin{tabular}{rrrrr}
\hline \hline Variable & Coefficient & Std. Error & t-Statistic & Prob. \\
\hline C & 3.655658 & 0.068724 & 53.19331 & 0.0000 \\
RGDP $_{\text {MS }}$ & 0.388388 & 0.147546 & 2.632295 & 0.0133 \\
MPR & 0.394148 & 0.129505 & 3.043495 & 0.0049 \\
EXR & 0.400720 & 0.118670 & 3.376744 & 0.0020 \\
INF & -0.214770 & 0.031586 & -6.799552 & 0.0000 \\
\hline \hline R-squared & -0.002958 & 0.021174 & -0.139687 & 0.8899 \\
Adjusted R-squared & 0.984349 & F-statistic & & 364.7837 \\
Prob(F-statistic) & 0.981651 & Durbin-Watson stat & & 1.983364 \\
\hline \hline
\end{tabular}

Source: E view 9 Statistical Package, (2019)

Table 3 presented the fitted regression result for hypothesis on banks' credit contributions to economic growth performance in Nigeria using macroeconomic indices of real gross domestic product, money supply, monetary policy rate, exchange rate and inflation. Statistical evidence from the result denoted that real gross domestic product, money supply, monetary policy rate have positive contributions towards banks' credit growth and economic growth performance in Nigeria while exchange rate and inflation rate contributed negatively but insignificant to banks' credit growth and economic growth performance in Nigeria. In particular, the result denoted that real gross domestic product has coefficient value of 0.388388 which implied that ceteris paribus real gross domestic product could contribute positively and significantly to banks' credit growth and economic 
growth performance in Nigeria by 38.88 percent. More so, money supply had a coefficient of 0.391448 which represents 39.14 percent contribution to banks' credit growth and economic growth performance in Nigeria Furthermore, monetary policy rate explained its important contributions to banks' credit growth and economic growth performance in Nigeria by revealing its coefficient value of 0.400720 which indicated a 40.07 percent. This denotes that if Deposit Money banks make judicious use of the Central Bank' credit guidelines, it will positively and significantly contribute to banks' credit growth and economic growth performance in Nigeria by $40.07 \%$. However, inflation rate has once again proved its negative but insignificant and unstable effect on banks' credit growth and economic growth performance in Nigeria. This indicated that inflation rate does not contribute to banks' credit growth and economic growth performance in Nigeria positively rather it retards the growth of the economy by its coefficient value of -0.002958 which appeared more insignificant with $-00.29 \%$ related to economic growth in Nigeria. Conversely, the result revealed the negative relationship between inflation rate (INF) and exchange rate (EXR) on economic growth performance. This thus implies that an effort to further increase inflation rate and exchange rate will negatively decrease banks' credit growth and economic growth performance in Nigeria by $21.5 \%$ and $00.1 \%$ respectively. The findings that were positive and statistically significant were achieved as a result of the long run effects of financial liberalisation of the economy, the banking sector reforms that runs through banks consolidation this strengthens the capability of banks to lend huge credit to willing investors coupled with the diversification of banks' portfolio and the frequent management of monetary policy rate introduced during the reforms by monetary policy committee.

As evidenced by the probability and t-test statistics, it is important to note that real gross domestic product, money supply and monetary policy rate have significant effects on banks' credit growth and economic growth performance in Nigeria represented by aggregate bank credit to the private and public sectors while exchange rate and inflation has pronounced statistical insignificant effects on banks' credit growth and economic growth performance in Nigeria. The Adjusted $\mathrm{R}^{2}$ value of 0.981651 signified estimated $98.16 \%$ of the independent variables on economic growth performance, that is, the real gross domestic product, money supply, monetary policy rate, exchange rate and inflation rate variables contributed about $98.16 \%$ variation on banks' credit growth in Nigeria while the remaining $1.84 \%$ were accounted for by the stochastic variables that were not represented in the study.

Nonetheless, the F-statistics of 364.7837 and probability value of 0.00000 indicated that the overall model is statistically significant against all odds. More importantly, the Durbin Watson test indicated that the value of 1.98 which is closer to 2 when approximated thus implied that the model is not bias and it is free from serial autocorrelation. By these revelations, the fitted regression model is said to be statistically significant and thus appropriate, reliable and acceptable for assessing banks' credit (credit growth) to banks' credit growth and economic growth performance in Nigeria.

The test for the economic or theoretical significance of the parameters was determined based on the sign of the estimated parameters; it, however, revealed that real gross domestic product, (RGDP), money supply $\left(\mathrm{MS}_{2}\right.$ ) and monetary policy rates (MPR) in Nigeria were positively signed. Thus, it implies that real gross domestic (RGDP), money supply $\left(\mathrm{MS}_{2}\right)$, monetary policy rate (MPR) positively contributed to banks' credit growth and economic growth performance in Nigeria during the period under investigation neglecting the insignificant implications of and exchange rate (EXR) inflation rate (INF). Thus, the result concluded that real gross product (RGDP), money supply $\left(\mathrm{MS}_{2}\right)$ and monetary policy rate (MPR) significantly contributed to banks' credit growth and economic growth performance in Nigeria. In respect to a priori expectation, it is concluded that the results are in alignment and consistent with the economic a priori expectation of positive and negative relationship respectively.

\subsection{Conclusions and Recommendations}

This study further examined the empirical analysis on determinants of bank credit growth in Nigeria: a supply side approach and this is a meaningful addition to existing literature- expecially in Nigeria - by providing empirical indication. All the variables used were stationary after first differencing indicating a short run relationship among the macroeconomic variables applied. Furthermore, the correlation matrix analysis result also establish a meaningful relationship among the variables while the result outcome from the fitted regression test revealed that all the variables have positive contributions to banks' credit growth and economic growth performance in Nigeria while inflation rate contributed positively but insignificant to banks' credit growth and economic growth performance in Nigeria. Since a well developed business and economic growth performance demanded more credit which will automatically translate to credit growth as well. Though appropriate monetary policies in use and the financial reforms in the banking sector facilitate the enhancement of more credit to entrepreneur.

The short-run results and the fitted regression results do provide great support for the influence of banking sector reform on the growth of bank credit to private sector as shown by the coefficient for the dummy variables in Nigeria. Although it follows a different methodology from the study of Assefa Million (2014) and Kashif 
Imran and Mohammed. N (2013) but the outcome established that all macroeconomic variables used are statistically significant as an instrument of determinants of bank credit in Nigeria.

Not that alone, if bank credit is to play a profitable role on bank credit growth, exchange rate and increasing inflation rate should be visited with utmost urgency, this is evidenced by the revelation of the study output where exchange rate and inflation have negative effects on economic performance. This has hindered the growth and progress of the real sectors in Nigeria. Mainly the negative trend of inflation rate and exchange rate can thereby sends bad signals to investors as the rate of inflation and exchange is always on the increase. Government is implored to put forward proactive measures and programmes that can meaningfully bring down the increasing exchange rate and inflation rate which has sent many investors away from doing business in Nigeria. It is the findings of the researcher that if all these policies are implemented successfully, these will do the Nigerian government lots of good than evil.

More so, efforts by banks' managements and authorities to increase the volume of banks' credit to the society will not be swept under the carpet as it will further strengthen and accommodate more investments and profitable projects into the economy which in the long run will provide job opportunities, reduce unemployment, reduce poverty level and contribute to the economic development of Nigeria. However, in doing this, banks' management should not forget that some customers can be dubious at times; therefore, banks should establish a monitoring team that is capable of supervising the projects that loanable funds are meant for. Also, the money should be given in tranches to avoid channelling of fund for another purpose.

The implication that arose from the study is that monetary authority needs to be effective in controlling and mobilising funds within the system. If money supply is circulated around the economy, it will reach the hand of business men and women thereby leading to investment creation. More so, effective policies that will further strengthen the deposit money banks in facilitating their credit to the private sector without stringent conditions should be visited. In turn this will lead to economic sustainability.

\section{REFRENCIES}

Baoko. G., Acheampong, A.I., \& Ibrahim.M., (2017). Determinants of bank credit in Ghana: A bounds-testing cointegration approach, African Review of Economics and Finance. 9(1)33-39

Central Bank of Nigeria. (2019). Central Bank of Nigeria Financial Stability Report.

Million .A. (2014). Determinants of growth in bank credit to the private sector in Ethiopia: A supply side approach, Research Journal of Finance and Accounting. 5 (17) 90-101.

National Bureau of Statistics (2019) Download Statistics on Banks Financial Statements

Kai G., \& Vahram. S. (2011). Determinants of bank credit in emerging market economies. International Monetary Fund. IMF working paper WP/11/51. 1-20

Kashif .I \& Mohammed N. (2013). Determinants of bank credit in Pakistan: A supply side approach. Economic Modelling 35 (2013) 384-390. journal homepage: www.elsevier.com/locate/ecmod

Olokoyo, F. (2011). Determinants of commercial banks' lending behaviour in Nigeria. International Journal of Financial Research, 2(2), 61-72.

Langat, R, C. (2013) Determinants of lending to farmers by commercial banks in Kenya. Unpublished M.BA. Dissertation, University of Nairobi, Nairobi, Kenya. 